academic and administrative autonomy, internationalization, freedom of expression, faculty and student diversity, job placement, infrastructural facilities, and admissions processes, among other areas.

DOI: http://dx.doi.org/Io.6oI7/ihe.20I7.9I.993I

\section{The Cultural Mission of Premier Universities in East Asia}

\section{RUI YANG}

Rui Yang is professor and associate dean for cross-border and international engagement at the Faculty of Education, University of Hong Kong, China. E-mail: yangrui@hku.hk.

A new set of university rankings strengthens the notion that East Asia is fast becoming the next higher education superpower. With its unique traditions, East Asia attempts to indigenize the Western concept of a university that has dominated the world for centuries. Higher education systems in East Asia have arduously explored an alternative model to combine Western traditions with their own. Such an experiment has significant theoretical and practical implications. Yet, coming to terms with East Asia's higher education development has turned out to be far more difficult than previously thought. This article reports findings from a recent study supported by the Hong Kong Research Grants Council, entitled “Integrating Chinese and Western Higher Education Traditions: A Comparative Policy Analysis of the Quest for World-class Universities in Mainland China, Hong Kong, Taiwan and Singapore" (751313H).

\section{Recent Developments and Their Assessment}

East Asian higher education systems have been fast improving in both quality and quantity. A modern higher education system has been established throughout the region. East Asia has become the world's third largest zone of higher education, science, and innovation. While Japan has long been a world-class powerhouse in science and technology, the growth of research in China, Korea, and Singapore is also impressive-and Taiwan is not far behind. At the institutional level, universities are rigorously setting global quality research as their performance standard. Such developments look even more remarkable when compared with other non-Western societies.

However, when assessing future development, one may be more skeptical. To some, East Asian universities are reaching the most exciting phase of their development, leaping ahead to join the distinguished league of the world's leading universities. To others, although East Asian universities have made tremendous strides in terms of volume and quality of research output, they generally still lag behind the best universities in the West. By and large, the notion of "world-class" status in East Asia has been more imitative than creative. Financial and other resources, combined with some innovation strategies, can only bring you so far. A kind of "glass ceiling" will be reached soon.

Studies of higher education reforms have been overwhelmed by powerful economic and political influences. A cultural perspective that gives weight to the impact of traditions on contemporary development has been lacking. It is interesting to note that both optimists and pessimists have cited East Asia's traditional culture in their argumentation. It is equally interesting to note that extreme views are usually expressed by external observers: for researchers within the region, both gains and losses appear to be more real. Yet, they have also failed to theorize how their universities differ from those in Western countries. This is despite their evident pride in the idea that East Asian universities are not willing to assume that Western models define excellence.

\section{A Narrowing Gap}

Traditional higher learning in East Asia was concerned with worldly affairs. Pragmatic moral and political concerns were favored over metaphysical speculation, with a central focus on statecraft and ethics rather than logic. Ancient East Asian higher learning institutions were established to serve the rulers, in sharp contrast with medieval universities in Europe. At the turn of last century, East Asian societies started to institutionalize modern higher education based on Western experience, as part of their wider social transformations in a context of national "salvation" and eastward movement of Western learning. From the outset, fundamental differences between East Asian and Western values have led to continous conflicts and laid out troubles for the future.

East Asia's unique cultural roots and heritages have greatly constrained the functioning of core Western values that underlie the concept of university. The coexistence of two powerful value systems that are not compatible with each other has proven to be the greatest challenge for East Asian higher education development. The Western concept has been adopted only for its practicality. There have been frequent attempts to indigenize the Western idea of a university and various societies have employed different approaches, but little has been achieved. This explains why achievements in science and technology are so much greater than in the social sciences and humanities. This is precisely the bottleneck of East Asia's higher education de- 
velopment.

However, East Asia's century-long hard and bitter work has begun to bear fruit. Defining the values of the university is gradually taking root throughout the region, most evidently at the individual level. An overwhelming majority of participants in my research acknowledged growing autonomy granted to their institutions. Even those who were concerned about the negative role of traditional culture and called for "seeking truth and freedom," agreed that much progress has been made. Such progress contributes to the narrowing the conventional gap between Western and East Asian ideas of a university. It interrogates mainstream views that predict an impasse of East Asia's higher education development due to a complete lack of academic freedom and institutional autonomy.

\section{Cultural Experiment}

As a latecomer, East Asia's modernization involves a response to Western challenges. The desire to catch up with the West has always been fervent. All participants mentioned major global universities frequently and, without exception, those were Western institutions. It was common to hear them refer to Western universities when talking

\section{East Asian higher education systems have been fast improving in both qual- ity and quantity.}

about their international networks, strategic partners, and positions in global rankings. The fact that all participants showed a rich understanding of Western society in their talks has to be understood in a context of a contemporary East Asian society and culture that have been profoundly influenced by the West. Western learning has become part of East Asia's knowledge system. It is already impossible for East Asians to talk about education without mentioning the West.

East Asia's higher education elites and scholars believe that the conflicts between traditional and Western values can be resolved. This confidence was repeatedly confirmed during my fieldwork. East Asia's intellectual tradition has its strength, and good potential to contribute to the idea of a university. After painstakingly learning from the West during more than a century, East Asians are now well positioned to get the mix right. Their flexible and open perspective allows them to appreciate opposing poles as a driving force and see opportunities in contradictions. Their prag- matic approach to life enables them to use whatever helpful means are available to solve problems. They do not have to choose between the East Asian and the Western university models: they can use both simultaneously and flexibly.

Both traditions are deeply incorporated into the daily operations of elite East Asian universities. East Asia is making a cultural experiment with emerging signs of hope. East Asian universities appear increasingly able to turn scars into stars. Unlike their prestigious cousins in the West, who have a poor knowledge of other parts of the world, East Asian academic elites know the West as well as their own societies. While Western universities operate in a largely monocultural environment, East Asia's flagship universities work in a combined culture that includes at least East Asia and the West. Such a combination is globally significant and historically unprecedented.

\section{Conclusion}

With enormous progress in spite of serious challenges, growing evidence shows that East Asia is likely to reach further by integrating Western and traditional cultural values. Premier universities in East Asia are exploring an alternative path to a future development with global implications. Their experiment has demonstrated the possibility of striking a balance between East Asian and Western ideas of a university that are conventionally perceived as mutually exclusive. While it is too early to predict East Asia's success, the process is certainly full of promise.

DOI: http://dx.doi.org/Io.60I7/ihe.20I7.9I.10038

\section{The Slow Path to General Education in Chinese Uni- versities}

\section{Bie Dunrong}

Bie Dunrong is professor and director of the Center for Higher Education Development Research, and deputy dean of the Institute of Education, Xiamen University, China. E-mail: yү241504@foxmail.com.

G eneral education is an important theme in the context T of current university-level education reform in China. The main purpose of this reform is to broaden students' general knowledge, extend their vision of the world, and strengthen their capacity to solve complex problems. Many universities have launched their own general education programs, while others have taken steps to improve general 